\title{
Post-truth Politics, Performatives and the Force
}

\section{Patrik Fridlund ${ }^{1}$}

Accepted: 23 October 2020 / Published online: 5 November 2020

(C) The Author(s) 2020

\begin{abstract}
This paper on post-truth politics argues that to the extent that one wants to understand political discourses generally (post-truth political discourses in particular), it is crucial to see them as circulating talk that performs rather than reports. This implies a shift in focus. Many react strongly to 'post-truth' assertions by appealing to evidence, objectivity, facts and truth. In this paper, it is suggested that, when analysing political discourses, there is no point asking, 'Is it true?' One should rather ask, 'What happens as a result?' Understanding political discourses as performative demands that the resulting doing, transforming and changing may transcend established parameters and known patterns. That also means problematising the types of argument allowed, or discourse considered appropriate, in a given situation. What, then, is the force within the performative discourse driving transformation? What role does intention play? And who-if anybody - can be designated as the master of the discourse? One way of answering these questions is to broaden the perspective of what happens in verbal exchanges. The hearerspeaker relation is fundamental, one in which meaning is shaped and the performative force is formed. A political discourse in general, and a post-truth political discourse in particular, cannot do and perform - cannot function - in a vacuum. This evokes serious questions about accountability and responsibility and also about human action and freedom.
\end{abstract}

Keywords Post-truth politics · Political discourses · Trump · Performatives · Austin · Derrida · Speaker-hearer responsibility

Patrik Fridlund

patrik.fridlund@ctr.lu.se

Centre for Theology and Religious Studies, LUX, Lund University, Box 192, SE-221 00 Lund, Sweden 


\section{Introduction}

A 'post-truth society' has been defined as one in which " "objective facts" are less influential in shaping public opinion than appeals to emotion and personal belief'. ${ }^{1}$ The loaded term 'posttruth' is used to describe a broad stream of events and attitudes frequently perceived as a threat, particularly to science and politics. For example, the distrust of science found in a post-truth society is often seen as degenerative and destructive of democracy. ${ }^{2}$ Although it is almost a ritual to refer to the fact that the term was the Oxford English Dictionaries word of the year in $2016,{ }^{3}$ the elaborate characterisation differs of course from one author to another. Political scientist Ari-Elmeri Hyvönen understands the term post-truth politics as describing 'a predicament in which political speech is increasingly detached from a register in which factual truths are "plain", 4 while political theorist Saul Newman lists a number of what he considers typical traits - propagation of falsehoods, lies, misinformation, outrageous exaggeration and distortion of reality, and more. ${ }^{5}$ Typically 'post-truth' is something that is said to have gained terrain recently. ${ }^{6}$ Hyvönen sees in post-truth politics an erosion of shared facts and of common sources of information, which makes the situation historically unique. ${ }^{7}$ Political scientist Manuel Cervera-Marzal takes a very different stand arguing that those who actively use the term post-truth also thereby make claims that the world has entered a new era, which CerveraMarzal finds ridiculous. It is built on the assumption that there was a time when political debates were marked by facts and when those who governed acted according to truth and were evaluated on the basis of objective facts. ${ }^{8}$ Other scholars claim, more modestly, that quite a number of post-truth traits are present in public discourses since long. ${ }^{9}$ Neurologist Sebastian Dieguez takes a somewhat more pragmatic position. Even if the situation is not absolutely new, 'post-truth' may be a useful notion in a particular way simply by making us understand a possible situation regarding the cognitive relation humans have with the surrounding world and with themselves, he suggests. ${ }^{10}$

Another debate is the one around the relation between bullshit and post-truth. Hyvönen spends some time explaining the distinction between bullshit and post-truth, drawing heavily on the analyses of bullshit as discourses carefully chiselled out with much attention paid to every detail, in contrast to careless post-truth discourses. ${ }^{11}$ In this article, that kind of distinction is unhelpful. First, how do we know that for instance Donald Trump has not crafted his speeches more and in other ways than they appear. Second, in this study, I am less interested in the amount of time someone has spent preparing, or not spent preparing a public appearance, as I look into the effects and how they may be understood.

Post-truth has attracted much interest in academic circles lately, and many different projects have been shaped. Hyvönen aims at working on the conceptualisation of post-truth in order to

\footnotetext{
${ }^{1}$ Oxford English Dictionaries Online, accessed 26 May 2018.

${ }^{2}$ See Thompson and Smulewicz-Zucker 2018.

${ }^{3}$ See Newman 2019, 93; see also Hyvönen 2018, 38, where the Gesellschaft für deutsche Sprache is brought in as well: 'postfaktisch' was the word of the year 2016 in this German-speaking context.

${ }^{4}$ Hyvönen 2018, 38.

5 Newman 2019, 94-95.

${ }^{6}$ Renner and Spencer 2018, 315; Sayer 2017, 92.

${ }^{7}$ Hyvönen 2018, 45.

${ }^{8}$ Cervera-Marzal 2019, 35, 41.

9 Poole 2017, 42-43.

${ }^{10}$ Dieguez 2019, 2.

${ }^{11}$ Hyvönen 2018, 43.
} 
make the phenomenon more visible and thus facilitating a deeper analysis leading to a broader approach to truth in political science. ${ }^{12}$ Political scientist Ignes Kalpokas has some affinity with Hyvönen in the way that post-truth is approached through conceptual history or history of ideas. The aim is to understand what is perceived as a shift towards post-truth in terms of 'escapist romantic fantasy that masks the underlying reality of guilt'. ${ }^{13}$ Political scientist Sebastian Schindler is seeking to establish greater clarity regarding the phenomenon posttruth politics in relation to the implications this very phenomenon has for contemporary critical thinking. ${ }^{14}$ In the present study, the scope is a slightly different one. This essay focuses on post-truth politics, arguing that concentrating on political discourses as declarative fails to understand their performative character and their force.

A good example of post-truth politics is, of course, provided by President Donald Trump, who was for many years before entering politics a well-known public person and businessman. Of his way of working and making deals he observes:

I play to people's fantasies. People may not always think big of themselves, but they can still get very excited by those who do. That's why a little hyperbole never hurts. People want to believe that something is the biggest and the greatest and the most spectacular. I call it truthful hyperbole. It's an innocent form of exaggeration - and a very effective form of promotion. ${ }^{15}$

The key here is that Trump tells people what they want to hear, applying what he sees as slight exaggeration, as 'truthful hyperbole'; what he says is a bit more and a bit better than the truth but also not entirely without foundation. In Trump's 'post-truth' attitude, 'objective facts' are less important than emotions and personal beliefs. His attitude corresponds well to many of the epithets of post-truth given above.

While Trump offers a good example of post-truth politics, there is something that interests me beyond the concrete case of Donald Trump. Rather, he brings to the fore traits in political discourses more generally; they are simply more visible in the extreme and reckless use of language in post-truth politics. In post-truth politics, people do not even pretend that 'objective facts' are significant - there are always 'alternative facts' - while for instance emotions and personal beliefs are valued. ${ }^{16}$ Moreover, political scientist Guiliano da Empoli argues that in this new political landscape, political agents - like the Movimento cinque stelle (Italy), the focus of his study, or Donald Trump ${ }^{17}$ - function as platforms with no political content, no programme and no vision: they are empty. ${ }^{18}$

This overt disinterest in 'facts' and the programmatic vacuity of content have contributed to a crisis in contemporary society. The question addressed here is how this should be understood and how it should be dealt with. This essay begins with a brief look at an important mainstream academic reaction to post-truth politics, highlighting what most seems to upset philosophers and others. This is followed by my understanding of the raison d'etre and the very functioning of political discourses, indicating that much of this mainstream reaction largely misses the

\footnotetext{
${ }^{12}$ Hyvönen 2018, 32.

13 Kalpokas 2018, 1127.

14 Schindler 2020, 393.

15 Trump and Schwartz 1987, 58.

16 See, e.g. Newman 2019, 94-95, 97-98.

${ }_{17}^{17}$ See, e.g. Klein 2017.

18 da Empoli 2019, 38, 66.
} 
point. A structuring idea of the discussion is that, in certain ways, post-truth political discourses function as political discourses are supposed to function. Then, very much inspired by a short text written by philosopher Jeffrey Nealon, I launch the idea that political discourses can be characterised as performative, in the sense of transforming and creating reality, before finally examining the force of political discourse - that which makes the discourse perform. Obviously, the work of J. L. Austin plays an important role, but it should also be clear that I have no ambition to perform an exegesis of his oeuvre.

The performative aspect of political discourse - that is, its transformation and creation of reality - entails that it also has the potential to transform the rules and the frameworks of the discourse itself. This has far-reaching implications. To what extent is it possible or useful to exit the conventional structures and overthrow established rules when change is sought? And what is the force driving the transformation? Questions must be raised regarding the role of intention and who - if anybody - can be designated the master of the discourse. One way of doing this is to broaden the perspective of what happens in verbal exchanges. The hearerspeaker relation is fundamental, as a double-sided relation in which meaning is shaped, and the performative force is formed. This evokes serious questions about responsibility and also about human action and freedom, although, given the limitations of space, only a few can be considered here.

\section{Post-truth Politics as Resistance to Facts and Knowledge}

Swedish philosopher and member of the Swedish Academy, Åsa Wikforss, places post-truth politics in the 'postmodern' and general 'post-truth' context. In this manner, she joins a broad fellowship found both inside and outside academia reacting strongly against what is characterised as resistance to facts and reality, which in their view implies neglecting evidence and objectivity. It is, she says, important to be well-informed and have the right knowledge in terms of politics and political choices, as well as fundamental choices concerning what kind of society one prefers. ${ }^{19}$

Wikforss talks about 'resistance to facts' - although she personally prefers 'resistance to knowledge' - arguing that we must re-connect to facts, re-convert people to believe in evidence and base decisions on objectivity. ${ }^{20}$ What Wikforss calls 'resistance to knowledge' is akin to what other scholars call 'anti-intellectualism', including David Block who offers two examples of this phenomenon in politics. The first is leading Brexiter Michael Gove, who is reported to have urged people to stop listening to the warnings of experts regarding Brexit; the second is Bundeskanzlerin Angela Merkel, who is said to have claimed that we should trust experts less and trust common sense more. ${ }^{21}$ Making the point that people are actively discouraged from trusting experts, science and intellectually solid arguments, Block issues warnings against such anti-intellectualism. ${ }^{22}$

Post-truth thus provokes a philosophical reaction on various levels. There is, however, one trait that concerns this study more than others. Wikforss tells that more than a third $(35 \%)$ of the voters in the USA's presidential elections of 2016 did not know that Obamacare was the

\footnotetext{
${ }^{19}$ Wikforss 2017, 40-41.

${ }^{20}$ Wikforss 2017.

${ }^{21}$ Block 2019, 50-51.

22 Block 2019, 50-51; for a discussion on this topic, see Fuller 2018, 13.
} 
same thing as the Affordable Care Act. Consequently, many people who were against the former did not realise that this meant they were also against the latter. ${ }^{23}$ This can be read in two ways, and I think that Wikforss has a double message. On the one hand, it seems reasonable that people should know what they are voting for or against. If I want a particular political party to govern the country, it is of course unfortunate if I - for whatever reason - do not understand which ballot I should pick to express my desire and cast my vote according to my political preference. Certainly, one can agree with Wikforss that if voters do not understand which ballot to pick or if they are misled in this process, these are reasons to react and take measures. Philosopher Jacques Derrida is one of those who have been clear on this point: responsible decisions cannot be made without knowing what one is doing and without being conscious of what is being decided. ${ }^{24}$

There is, however, another message in Wikforss' text: the position of the values of 'objectivity', 'evidence', 'fact' and 'knowledge' in the political process. This is much more complex. I maintain that political choices are not primarily about facts but, rather, about orientation, direction and so on. Derrida perceives a tension or perhaps a paradox in this context. If making decisions is simply perceived as an issue of knowledge and if making decisions is limited to following some rule, then one must conclude that this simply represents a technical mise en cuvre of the cognitive apparatus, and consequently not about responsible choices. ${ }^{25}$ In the same vein, philosopher Jean-François Lyotard argues that a political discourse is not about knowing. A good theoretical description of a problem is not enough in order to know what should be decided. ${ }^{26}$ So, although responsible decisions and choices cannot be made if one disregards available information, facts and knowledge, it is equally misleading to think that responsible political decisions can be seen as straightforward outcomes of available information, established facts and acquired knowledge. As Lyotard points out, political utterances do not reflect a vision of the world that can be true or false. ${ }^{27}$ Therefore, political discourses must be read differently.

\section{Political Discourses}

A common struggle against post-truth politics, as outlined above, is not necessarily based on one specific understanding of politics. Yet there seems to be a bottom line, so to speak: it all turns on evidence, objectivity and facts. This is, however, problematic.

If focusing on these three elements, one is inclined to miss some very important aspects of politics and the conditions for political arguments. In politics, arguments are launched in order to create effects. Consequently, they are best understood as pragmatic. The goal of a political argument is to garner support for a project. The objective is not to present a veridical report of some state of affairs; nor is it about making a self-declaration in which the speaker gives their view on a particular topic. According to social epistemologist Steve Fuller, the aim of the politician is simply to be perceived as someone with such strong convictions about their political vision that they are prepared to do whatever it takes to bring it about. This in itself attracts enough support to turn the vision into reality. It becomes a self-fulfilling prophecy.

\footnotetext{
${ }^{23}$ Wikforss 2017, 40-41.

${ }^{24}$ Derrida 1999, 43; Derrida 2003, 199.

${ }^{25}$ Derrida 1999, 43; Derrida 2003, 123-124, 199.

${ }^{26}$ Lyotard 2006 [1979], 65-66.

${ }^{27}$ Lyotard 2006 [1979], 129.
} 
That means that the politician indeed participates in producing the reality for which they strive. $^{28}$

\subsection{Political Discourses as Performative}

In a slightly different vein, Nealon expresses the insight that politicians create or produce reality by their discourses. Informed by readings of Austin and Derrida, he suggests that what is 'politically true' — or what can be called political truth —is, rather, performative, noting that 'political truth functions not on the logic of facts'. ${ }^{29}$ The notion of political discourses as performative is the axis for the rest of this paper.

In his Harvard lectures of 1955, subsequently published as How To Do Things With Words (1962), J. L. Austin launches the idea of performatives, identifying performative utterances as utterances that do not describe or report. Thus they are simply - in Austin's terminologyopposed to constatives, which entails that they are not true/false and that they cannot be true or false. Therefore, no argumentation is necessary or even possible. The leading principle is that the very saying of the utterance is (part of) doing. ${ }^{30}$ In other words, introducing performatives implies introducing the idea that to say something is to do something. In this fashion, Austin questions the idea that saying equals stating something. ${ }^{31}$ In this respect, performatives can be seen as freed from truth-value while having value as force. ${ }^{32}$

As Austin affirms, performatives are straightforward utterances that simply cannot possibly be true/false; rather, they do something - they perform. For instance, when 'yes' is uttered in a wedding ceremony, the utterance does something, it renders the utterer married. Neither the single phrase nor the web of utterances of which 'yes' is a part is a report or an account of their being married, desiring to be married or the like. Nay, the very saying of 'yes' does the job. ${ }^{33}$ What is central, and cannot be overstressed, is that Austin thus concludes that the utterance is not an exterior and audible sign of an interior act undertaken by the utterer. ${ }^{34}$ It works on its own, as it were. It is in this particular sense that political discourses are seen as performative. A political discourse is not (primarily) reporting something that is - or can be - true or false. The performative character of a political discourse means that it does something, it performs.

In this way, it can be claimed that, given the performative character of political discourses, they are saying things that do not aspire to truth status as they are in a different register. It can even be claimed that political discourses have a mission to go beyond what is presently at hand. In this manner, they transform reality by saying things that are not true, but only in the sense of not being there. The very point of a political discourse is to suggest a different situation, something better than what presently is. This particular performative trait of political discourses becomes much more visible in the post-truth politics exemplified by Trump's utterances. Everything that is otherwise called information, for instance, is questioned, and what many people call reports of facts are frequently labelled fake news; alternative facts are referred to without hesitation. There is not even an attempt to create or accept a common

\footnotetext{
${ }^{28}$ Fuller 2018, 136.

${ }^{29}$ Nealon 2017, 19.

${ }^{30}$ Austin 1976, 5-6.

${ }^{31}$ Austin 1976, 12-13.

32 Derrida 1988, 13.

33 Austin 1961, 222.

${ }^{34}$ Austin 1976, 13.
} 
framework for deliberations. In a sense, this is politics drawn to its extremes. Performing is all there is.

Now, it may be said that the performative character is perhaps only seen from the outside, from the observer's perspective. One might think that it looks different from the 'inside'; that, to Trump and his supporters, what he says is indeed reporting and describing reality. Yet this may represent a misunderstanding regarding registers of communication. Derek Ford points out that when Trump tweets 'FAKE NEWS!', it has a number of implications on a register beyond describing reality or giving an account of what is. When Trump bawls in this manner, he is expressing an objection or discontent. Here, Trump is asserting his belief of what should be, Fords claims. Seen in this way, Trump's tweet 'FAKE NEWS' is a performative utterance. A tweet like that is meant to organise and strengthen his side of the political fight, a function that is found in the very way the utterance is made. Hence, Ford continues, this particular usage reflects a perception of language as something more and different than a simple tool or instrument employed to transmit ideas. Consequently, Trump does not necessarily perceive this kind of utterance as something conveying a particular ideational content supposed to persuade the hearer. Not even from an inside perspective is the utterance thought of as a report that is true (or false). It appears rather to be the force of the utterance, as a performative utterance, that does the job. What it does is what counts, not whether truth is told or not. ${ }^{35} \mathrm{~A}$ good illustration of this is when Trump's press secretary states that " "Whether it's a real video, the threat is real" "36 or, in other words, what is said may be untrue but what counts is the force of the utterance, what is communicated is on another level.

What is suggested in this paper is that post-truth politics is here, whether we like it or not. Yet, to many, post-truth politics has deeply upsetting traits. Therefore, many react strongly, and there are many endeavours to counteract the trend. Crucially, however, such efforts must not be counter-productive more broadly; they must not undermine the conditions for political discourses altogether. The suggestion here is that not only post-truth political discourses may be analysed as performative but also that this is a general trait of all political discourses, a central part of their functioning. This must be taken into account, I suggest, when understanding post-truth politics and countering its destructive aspects. If political discourses are seen as performative, a shift in focus is called for. There is no point asking, 'Is it true?' Rather, one should ask, 'What happens?'37 One consequence of this is that the 'force' of the utterance becomes a matter of interest - the topic addressed in the following section.

\section{Performatives and Force}

As mentioned above, Derrida holds the value of performatives to be independent of 'truth' while retaining the value of 'force'. In a similar vein, Quintin Skinner claims that when understanding an utterance, it is indeed necessary to understand both the meaning and 'the force with which the utterance is issued': that is to say, not only what people say but also what they are doing in saying what they say. ${ }^{38}$

\footnotetext{
${ }^{35}$ Ford 2019, 9.

${ }^{36}$ Ford 2019, 9.

${ }^{37}$ Sesonske 1965, 461

38 Skinner 2002, 82.
} 
The aspect of force is elaborated in Derrida's reading of Austin, in which Derrida concludes that performative speech acts communicate original movement - a performative would be communicating a force - rather than transferring particular thought-content. A performative 'produces or transforms a situation'. A consequence of this is that the performative that performs and does when being uttered - thereby performing its role as performative - is not describing something outside of language, something prior to it. While the same can be said about a constative, it cannot be said to constitute the internal structure of a constative, as compared to the performative. ${ }^{39}$ Hence, the performative dimension undermines the referential relation between 'sign' and 'object'. In this way, a performative utterance is one in which language acts independently of its referential function. ${ }^{40}$ Derrida suggests, therefore, that Austin might seem to have broken with the concept of communication as strictly semiotic, linguistic or symbolic: a performative is not purely transferring semantic content. ${ }^{41}$

Consequently, if political discourses are analysed in terms of performing and creating or producing and transforming reality, the issue of force becomes vital. This is even more applicable to post-truth politics. Therefore, understanding the constitution and functioning of 'force' becomes necessary, as well as how this 'force' is formed and whence it finds its energy. How is it formed and articulated? What gives the performative the force to do what it does? Two paths are identified. First, the force of a performative utterance may be seen as constituted by procedures - a performative cannot function unless the utterance is accomplished according to certain rules that make it perform what it performs. Second, performing and thus creating reality must also entail potentially breaking with procedures to the extent that creating, producing and transforming reality are taken seriously.

\subsection{First Path: Procedures as Constituting Performatives}

Austin suggests that some conventions and certain circumstances must be present in order to make a performative utterance function happily (or be 'felicitous' in speech-act jargon): an issue concerning the force it has and how well it functions. ${ }^{42}$ One could say that, to Austin, a performative must be uttered in a given way in order to have the force to do or precisely perform. $^{43}$

Austin identifies a number of 'rules' or procedures for a performative to function. It must be uttered within an accepted conventional procedure, by some appropriate agent and in appropriate conditions (for instance, the person naming a ship must have been appointed to do so; the utterance alone is insufficient). The procedure must be effectuated correctly and completely: the utterer must have the expressed thoughts and feelings, and those concerned must intend to implement them and must behave accordingly. ${ }^{44}$ If these requirements are not fulfilled, the performative is without force; it cannot do, it cannot perform. ${ }^{45}$ If the act is not completed, it may be labelled a misfire. In so far as the act is implemented completely but not sincerely, it

\footnotetext{
${ }^{39}$ Derrida $1988,13$.

${ }^{40}$ Manrique 2012, 308.

41 Derrida 1988, 13.

42 Austin 1961, 224-226.

${ }^{43}$ Hominh 2016, 427.

44 Austin 1961, 227; Austin 1976, 14-15.

45 Austin 1976, 15.
} 
has to be classified as an abuse of the procedure: for instance, if the utterer does not intend to follow up on the act. ${ }^{46}$

This reasoning about procedural criteria is attractive. Still, there are many examples of situations that complicate the picture. For instance, if the person naming a ship has not been appointed to do so, the utterance lacks force. Hence, the utterance is without effect and does not perform what it seems to perform. Yet it may so happen that the act is accepted in spite of this afterwards, and the performative utterance becomes exactly that - performative. This may be the case, for instance, if those who are present believe that the naming has been effectuated; or, if the symbolic or pecuniary costs are too high, it may be better to accept what has happened rather than going through the process once again - correctly, completely, in appropriate ways with appropriate agents, and so on. In this case, the performative did not conform to given procedures but was still acknowledged.

Apparently, sometimes a false promise may be valid. An illicit declaration of independence may create independence. A fake priest's rituals - baptism, marriage, confession and the like - may be valid in spite of not conforming to prescribed procedures or conventions and inappropriately effectuated as the agent is not recognised by the appropriate authorities and so on. Such rituals may be valid even if they are illegal from the point of view of canonical law. And, of course, there are also cases in which the procedure is incomplete or undertaken in the incorrect way. There seem to be degrees of what is acceptable. Perhaps there is some hierarchy, some things that are indeed essential and others that are important but not vital. It seems most likely that it would be possible to forget a word, to pronounce something incorrectly, to be inaudible or similar in a wedding ceremony, yet still the marriage would be acknowledged and the parties registered as married.

In order for a performative to perform, it must fulfil some requirements. The problem is that apparently it is not difficult to circumvent such procedural requirements. The need for procedure or framework or conventions can be approached differently, however.

\subsection{Second Path: Performatives Beyond Procedures and Conventions}

Once again, performatives do something, they produce effects. Speech acts that, for example, inform or warn have effects. Yet performatives never stand alone; Austin claims that some background is always required for the effect to be produced, observing that, for instance, an utterance like 'there is a bull in the field' can be a warning, but does not have to be; it can also be mere description. The situation - the background - seems decisive here. ${ }^{47}$ This turns the importance of procedure and background around: instead of making a list of requirements for a pre-established procedure, and instead of beforehand defining the appropriate components of the background, the analysis may be reversed. The context does form a background that orients the force of an utterance in one direction rather than another, and, further, there are a number of elements that give the utterance a particular force; nonetheless, they do not necessarily follow a simple pattern or particular convention.

As a matter of fact, Austin points out that effects can come about, on the one hand, in and by utterances following certain rules leading up to the effect - for example, a warning uttered according to a given procedure will have the effect of a warning, it will perform a warningand, on the other, through purely effect-producing acts not following any such procedure. The

\footnotetext{
${ }^{46}$ Austin 1976, 16.

${ }^{47}$ Austin 1976, 32-33.
} 
difference is, then, that certain acts are conventional, while others are not. ${ }^{48}$ Pursuing an analysis of Austin, philosopher Yarran Hominh finds that he distinguishes between, on the one hand, an act in which something is done directly as something is uttered - in the utteranceand, on the other, an act in which what is done through the utterance is done so indirectly-by the utterance. In the first case, the act 'takes effect', while the latter 'produces consequences'. 49

According to Skinner, making such a distinction is essential: that is, between what is done in saying (directly) and what happens by saying (indirectly), providing the reason for separating conventional acts from acts not bound to convention. ${ }^{50}$ Philosopher John R. Searle makes a significant contribution regarding the reasons for maintaining this distinction by exploring the conventional procedures for utterances to do things. Searle claims that effects not bound by the conventions of our utterances must be left aside in analyses of speech acts as communication. The reason for this is that effects as simple consequences of an utterance, and thus unrelated to any procedure or established conventions, cannot be claimed to constitute responses to the utterance in a meaningful sense of the notion 'response'. In Searle's analyses, a meaningful relation between an utterance and its response must be tied to language as a system of communication built on some kind of systematic use of signs. Hence, in Searle's view, an act-effect relation unrelated to language as an institution-that is, a system of communication - is of no interest when understanding human agency in the form of linguistic utterances. Thus, the distinction between utterances that take effect as a result of conventions and utterances producing consequences unbound by convention must be maintained. ${ }^{51}$ It appears that, to Searle, what is at stake is the understanding of language as an institution, a structure stable enough to convey meaning and transfer information. Without this institutional character, Searle seems to be claiming that utterances and their effects would be reduced to some 'stimulus-effect' relation. That, in turn, would eliminate the speaking subject as an acting subject. The idea is that it would make the speaking subject redundant and utterances void of intention and responsibility.

In a similar manner, philosopher Jürgen Habermas' account for 'communicative action' places such acts as simply produce consequences within the irrational sphere. ${ }^{52}$ In this fashion, Habermas' analysis is directed to argument and to communication that must necessarily comply with certain rules. The analysis is focused on claims unavoidably made as soon as one starts reasoning, that is to say being focused on communication in the sphere of rational exchanges and on the implicit acceptance of a given logic and the perception of communication as cognitively based. ${ }^{53}$

There is an interesting cleavage based on the questions that are asked and the purpose of the investigation that has to do with how performativity is understood. Is it a technical term applicable only to a more or less clearly defined class of speech acts? Or should performing and doing be seen in a broad sense? On a fundamental level, this reflects different positions regarding the prerequisites and character of human action. On the one hand, there is Searle, who wants to elucidate certain mechanisms by investigating the structure of language functioning as a system of communication. To him, such a system enables human action - that is to say, someone saying things with certain intentions, producing effects in other people and thus

\footnotetext{
48 Austin 1976, 121-122.

${ }^{49}$ Hominh 2016, 436; see also Austin 1976, 117.

50 Skinner 2002, 104.

${ }^{51}$ Searle 1983, 178-179; Searle 1969, 71.

52 Habermas 1984 [1982], 99-101; see also Hominh 2016, 425.

${ }^{53}$ Habermas 1990, 58, 81.
} 
transforming the situation according to a particular intention. This position is most reasonable, I think.

On the other hand, one can also argue that the approach here represented by Searle is less appropriate when it comes to understanding political discourses beyond technical analyses of particular aspects, as the very idea of political discourses may be characterised precisely as breaking with the system. Fuller, for instance, observes that, typically, a political actor actively takes part in producing the reality they want; they do not only undertake modifications within a given framework. ${ }^{54}$ In this respect, the force seems to come from radical breaches, that is to say, refusing to play according to a given system of communication. The transformation is obtained from not being in conformity with established structures or procedures. This is a way of producing reality.

Of course, it could be claimed that politicians who want to intervene rely on language as communication. Within the framework - and only with the help of framework - transformation and change can take place; only with the help of conventions can political discourses both $d o$ and perform. Performative utterances are only identifiable if they appear as such, that is to say functioning as performatives. And I do agree. As Derrida puts it, science, knowledge and perhaps even language as such are dependent on structures and frameworks in order to function. ${ }^{55}$

Scientific progress, the production of knowledge and communication are, indeed, formed within certain structures. Structures and frameworks are required if things are to become clear or even understood. Arguments must be recognised and utterances be comprehended if a discourse is to be able to transform anything. Thus, there is nothing odd in the conviction that human action needs human language as an instrument, that is to say, as a means of communicating some particular content. If there is no identifiable structure, no particular content can be transferred and human action would be frustrated. I think this underpins Searle's position, and that it is correct, but only in so far as it is not the final word. There must also be space for events that are not allotted a place or a time, not foreseen and not foreseeable - in this respect thus being impossible. Innovation and newness can only take place if what takes place is impossible in the sense of not already being imagined or planned — not predictable — or so Derrida claims. Otherwise, we are not talking about an innovation or an event, and there is no change or transformation. ${ }^{56}$ Hence, while Searle finds it essential to have a structurelanguage as a system of communication - in order for humans to express intentions and desires and thus transfer information and enable transformation, my approach differs - here following Derrida.

The requirements for human action and its character are not, however, the topic of this paper. What I want to say here is simply that the possibility, or the need, to talk about political discourses in terms of their 'performative' quality appears to be directly related to how human action is conceived. My position is that we need to see how post-truth politics entails a break with convention. This underlines and emphasises the character of political discourses and brings them to their extremes, or even beyond. Now, this break can be seen as creating space for new and other conventions, although it need not be 'progressive'; it may equally imply

\footnotetext{
${ }^{54}$ Fuller 2018, 136.

${ }^{55}$ Derrida 2003, 176-177, 198.

${ }^{56}$ Derrida 2003, 180, 188, 197, 203.
} 
going back or fighting for the status quo. ${ }^{57}$ Still, I maintain that a break is a vital element of post-truth politics.

Therefore, the challenge attendant on post-truth politics requires a fresh look and a more radical approach. To me it seems indeed helpful to approach the issue with the help of other tools. For instance, when Donald Trump's political discourses perform, I argue that they do so at an additional level to the 'conventional' and that they perform in other ways than by speech acts technically identified as performatives. ${ }^{58}$ da Empoli argues that Donald Trump, for instance, in his discourse and perhaps by his discourse, elevates himself as a Leader-one above and other than common leaders; Trump appears as liberated Leader, not a conventional pragmatic bureaucrat. Hence, Trump is seen as capable of creating - and he actually does create - his own reality. In this respect, he fulfils the expectations of the disciples. ${ }^{59}$ The dynamic is extremely performative. People vote with one major concern, or so da Empoli argues, and that is to shake the elite, those who have the power: 'Let's vote "leave" and make Cameron stop smiling' and 'let's put Hilary Clinton in prison'. ${ }^{60}$ The core promise in the populist revolution is about humiliating the powerful and mighty. This is obtained in the very moment the populists take the power. ${ }^{61}$

Trump's speeches make promises - also and in spite of him not saying that there is a promise and perhaps without him knowing that promising is at the heart of what he is sayingthat is, they do. There is a non-explicit promise, not spelled out and not formulated - and perhaps not even consciously made. Consequently, I do not analyse the political discourses as containing a certain number of performative utterances that can be analysed as such. The point is rather that the totality may be understood as one, or several, performatives, even if some technical characteristics are absent. In this respect, such analyses come close to analyses of performances. Now, I think that analysing politics in terms of performance is more than adequate and very telling. Nonetheless, it is also important to retain the focus on the discursive aspect, understanding post-truth politics as post-truth verbal discourses.

I claim that keeping the discourse at the centre is essential. Therefore, I suggest a radical reading of post-truth politics, keeping in mind Austin's observation that what is central, and cannot be overstressed, is that the utterance is not an exterior and audible sign of an interior act undertaken by the utterer. ${ }^{62}$ One conclusion to be drawn is that a performative works on its own, as it were; that is, I think, a key. A consequence, I claim, is that political discourses do not obtain their force simply by complying with certain procedures. Or, rather, they can of course be seen as functioning according to certain patterns, yet, in important ways, they also bypass or create procedures. Post-truth political discourses make this obvious - their doing changes procedures, and displacement occurs due to the fact that so many things are shaken up: what seems to be a promise may not be one at all; facts that seemed to be important are no longer, but this is not always the case, and so on. In other words, the very structure of the discourse is fluid.

In his book on post-truth, Fuller shows that there is a conflict - a conflict of interpretationon a fundamental level. One part of this is that what Fuller calls 'post-truthers' aim to dissolve the frontiers between various knowledge games and hence make it easier to switch between

\footnotetext{
57 da Empoli 2019, 186-187.

${ }^{58}$ Cf. da Empoli 2019, 25.

59 da Empoli 2019, 25; see also Ford 2019, 9.

${ }^{60}$ da Empoli 2019, 75.

${ }^{61}$ da Empoli 2019, 75.

${ }^{62}$ Austin 1976, 13.
} 
them, or blend them. ${ }^{63}$ This questions the very structure of knowledge. What kind of experience counts and how is it validated? What type of arguments can be used in various domains? ${ }^{64}$ Fuller concludes that post-truth may be seen as bringing together issues that the authorities - both in politics and science - wish to keep separate. ${ }^{65}$

Here Austin is interesting. Discussing whether or not a particular act is conventionalbound to convention, rather than unconventional/ unbound to convention - when producing its effects, he also admits that he finds it difficult to distinguish between them. ${ }^{66}$ I claim that it is precisely this latter aspect that appears in Derrida's approach when he maintains that some given frameworks - conventions - are absolutely appropriate and useful when studying, describing and understanding various phenomena; to a large extent, that is presupposed in scientific enterprises. ${ }^{67}$ Thus scientific research that changes and transforms our dealing with the world is possible just because certain structures are mastered to perfection. To Derrida, working within established frameworks provides much-needed security and stability in several respects. This said, it must also be seen that, according to Derrida, one must not stop there. The code or conventional use can and must at times be questioned; there must always be a possibility to question the entire apparatus, so to speak. ${ }^{68}$

Talking about questioning in this fundamental sense implicates the importance of contextualising the structures, the code or the very convention at work. Obviously, everyone agrees that context has to be taken into account. What Derrida does emphasise is that context has to be taken into account not only provisionally, on the surface, or afterwards, later, as an extra, as something added. No, to Derrida, context is always 'at work within the place, and not only around it' ${ }^{69}$ That means that right from the start, and already within, there is a fissure that cannot be excluded or neglected. Concretely, this implies that although 'performative' is a useful category, distinct from the category 'constative', these categories must always be contextualised. Identifying structures and procedures involved in the functioning of 'performative utterances' is of course helpful. Yet what is at stake is whether this is enough. There is also a time when analysing these structures and procedures is insufficient.

The fundamental question is whether making limits porous is destructive or constructive: whether or not the philosophical investigation and reflection stop there. ${ }^{70}$ To me, the crucial issue is to what extent present knowledge and determined structures are sufficient and to what extent something other can be seen or has to be seen. It appears that in analyses of speech acts, for instance, it is presupposed that the context in any given individual case must be taken into account, but also that - at least theoretically - it can be known. Consequently, there is, in principle, an end point of the investigation. ${ }^{71}$ If so, this implies, both theoretically and in principle, the possibility of understanding what a political discourse is doing by analysing it through conventions and procedures. Anything beyond must be left aside. Anything outside this pattern must be considered non-political. Untreatable. It is precisely on this point I think that another analysis is required, and I do so informed by Derrida, as read by Hominh. When confronted with actual and real post-truth political discourses, technical analyses are

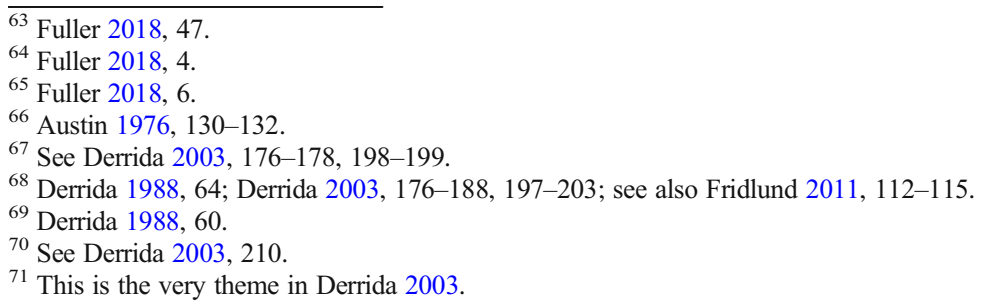


insufficient. What the political discourses $d o$ is that they rather produce and create reality as a function of rupture and as a break with what 'used to be'. They create something new, not by saying things within conventional structures and following established procedures, but by not behaving conventionally. Such performative political discourses can therefore be perceived as key moments - events - that form and transform reality. ${ }^{72}$

To me it seems that Derrida, in this manner, emphasises that there is and must be something unpredictable about human action - which means not possible, as a possibility necessarily is found within the range of what is predictable. Hence, in this particular sense, an event that is calculable or foreseeable cannot be an event. The unpredictable and not calculable delineate the exceptional singularity. ${ }^{73}$ The aspect of unconditionality in what cannot be calculated - the unconditional trait of the uncalculable - leads on to seeing 'the event' in the sense of something new that is about to occur, an adventure ${ }^{74}$, or the coming of the other in one's experience, as Derrida says ('venir de l'autre dans des expériences'). ${ }^{75}$

In this sense, it may be seen that the focus is on the force of the utterances that has effects, the unpredictable coming and the unforeseeable interruption of the other as a singular event. There are of course also foreseeable, predictable and calculable effects that follow a pattern. There are convention-bound effects, things taking place according to identifiable rules. That is not the issue here. What is at stake is whether philosophical inquiry and philosophical curiosity should halt here, or not.

This is a crucial question in any philosophical and discursive investigations of post-truth politics. It directly concerns the question of how to read Trump, for instance. His tweets may be analysed as lies, of course. But is it helpful? If Trump is read according to a conventional pattern of analysis, do we then miss the point? And what happens if post-truth political discourses are merely labelled 'bullshit'? Any political discourse will employ some of the same traits as Trump employs, so what happens with politics if everything he does in his political discourses is dismissed as bullshit? On the other hand, if post-truth politics is read in terms of performance, many interesting things may be seen, as in politics more generally, but if all is about performance, then philosophical arguments are made unavailable. Political and ethical arguments are also blocked out. What remains is a description of what can be seen. So, I claim that philosophical investigations must be undertaken even when they are difficult and when they are found on the margins of what is understandable and effable.

I also suggest that at least one more step must be taken. I suggest looking into the role of intention as a potential force in political discourses as performative, transforming discourses that indeed create something new.

\section{Role of Intention}

Austin suggests that, for a performative to function and perform happily, it is essential that what is said must be meant by the utterer; that is to say, it has to be uttered seriously. That also means that the utterer must have an intention that is expressed in an utterance. ${ }^{76}$ This accords with a prima facie understanding of how language works in general: there is someone (a

\footnotetext{
${ }^{72}$ Cf. Hominh 2016, 429.

73 Derrida 2003, 203.

${ }^{74}$ From the Latin adventurus, a thing about to happen, with an element of 'risk' but also of 'novel occurrence'.

75 Derrida 2003, 203.

${ }^{76}$ Hominh 2016, 427; see also Austin 1976, 10-11.
} 
speaking subject) who has something they want to communicate - an intention - that is effectuated by saying (or writing). ${ }^{77}$ The process seems fair enough. The speaker/author has a thought and the intention to communicate it, they express this thought verbally, and everything works fine to the extent the receiver can see and recognise the speaker's intention. ${ }^{78}$

This seems very reasonable. And yet, the situation is more complex. It seems that if intention plays a role in this way, it is precisely the role of being the inner process, reflected by or expressed in a given utterance. And that is, as a matter of fact, problematic.

Austin affirms that even though one may easily come to believe that there is an inner act of promising, for instance, and that the uttered promise is an exterior and audible sign of this inner act, it is impossible to assume any such inner, spiritual act undertaken by the utterer that should be added to what the utterance does. The problem then, Austin continues, is that in that case, the utterance would be reporting something, namely, a mental state. ${ }^{79}$ If the performative utterance were simply an exterior sign of some inner process or some inner act, that would ruin the very idea of a performative as something else than a constative that gives an account of something - here of an inner attitude, for instance. This is precisely counter to his definition of 'performative', thereby making the idea of intention problematic. And there is yet another perspective.

In his comments on Austin, Derrida states that intention is insufficient to determine the functioning of a performative utterance, as intention is simply too weak and fragile a measuring stick. If an intention is identified, it has to be something complex and 'problematic', as the intention in itself is not and cannot be undivided and whole. ${ }^{80}$ In simple terms, there is always a trace of something else and other in what is intended: a double, or a shadow, for example, as a contrast. Thus, an intention is also always more and something else, never full in itself and never entirely mastered by the intender. Consequently, there cannot be a simple inner act that is simply expressed in an utterance. ${ }^{81}$ That also implies that intention cannot animate an utterance from a strong position of independence; there is a 'structural unconsciousness' as it were. ${ }^{82}$ We have no choice but to mean something other than what we mean (to say). The utterance will go beyond the conventional framework - in an interesting and important fashion - and the utterance will say more and other than what seemed to be intended. ${ }^{83}$

Even more interesting, I claim (following Derrida), is that if intention were held to be the key, the author/speaker would also have to be considered the ultimate authority on the interpretation of what they say. If intention is the key, it presupposes that the decisive part of understanding how a discourse functions is that the author/speaker has something on their mind they want to communicate. And that should decide the reading. The problem is that the speaker/author would then, in a way, have a monopoly on what is performed, rendering their authority apparently invulnerable. ${ }^{84}$ One consequence of the speaker/author's having the ultimate (and absolute) authority regarding intention is that it would be impossible for someone who does not have direct access to the intention to read it; there would always and

\footnotetext{
${ }^{77}$ Fridlund 2011, 83.

${ }^{78}$ Fridlund 2011, 84; Larsson 1997, 44.

79 Austin 1961, 223; Austin 1976, 13.

${ }^{80}$ Derrida 1988, 18, 73.

${ }^{81}$ Derrida $1988,15$.

${ }^{82}$ Derrida 1988, 18, 73.

83 Derrida 1988, 61-62; see also Fridlund 2011, 83-87.

${ }^{84}$ Fridlund 2011, 85; Derrida 1988, 3-5.
} 
inevitably be a distortion. This reduces an utterance. Only the speaker/author knows what they intended to say in that case. ${ }^{85}$

Indeed, if the author/speaker and their intention govern all, all political debate would be useless. No opposition is possible if the speaker can simply respond, 'I did not intend to say that': 'If there seemed to be a promise...' or 'If the effect of my political campaign appears to be this or that... I am innocent, as I did not have any such intentions'. Ultimately, in this respect, only a monologue is possible. Hence, attributing a decisive role to intention in this fashion implies a double fault. First, an undivided intention is unthinkable. Second, even if there were an undivided intention, it would be pointless while exchanges of ideas, perspectives or opinions were excluded. Now, it has to be acknowledged that in Austin's work, intention is not analysed as a naked phenomenon. Intention is always embedded. For instance, for a performative to function, Austin requires that the person performing must not only have the expressed thoughts and feelings, and must intend to implement them, but also that they must behave accordingly. ${ }^{86}$

I suggest that Austin indicates a crucial point here. The importance of considering the context becomes clear in cases like those mentioned above involving a fake priest, a declaration of independence and the naming of a boat by an unauthorised person. Two things at least can be added. First, effects come about in and by a framework that is larger than intention. Second, even if the intention is lacking or is a different one from what it is said to be (in cheating, for instance), effects may come about. Rather, the question concerns the action-what happens and what takes place-as well as by whom this action is effectuated. Furthermore, by whom is it evaluated, judged or recognised? Once this has been said, it must also be stated that it does not entail absence of intentionality. That would be absurd. Of course, it is reasonable to count on people having intentions to do and say things while aiming to express such intentions in the best possible way. It would also be ridiculous not to want to hear such intentions. What is at issue is the presence of fulfilled and actualised intentionality and, consequently, the relevance of intention when attempting to grasp the force of (performative) utterances. $^{87}$

What can be seen here, I claim, is that reading political discourses as performative discourses seems to be a promising path; this approach casts light on the character of producing, changing and transforming, namely, the character of going beyond reality or beyond what is at hand. Now, if so, then it seems pointless to analyse political discourses solely in terms of being bound by conventions or tied to intention, in so far as the objective is to understand the character of change, transformation and breaking with what has hitherto been claimed. Still, producing, changing, transforming or, in other words, breaking with what is presently at hand... all that implies a force. At first glance, the speaker's intention seems to be the basis of an utterance's force, but it turns out to be quite difficult to rely on. Intention is simply too weak and fragile. Intention cannot animate an utterance from a strong position of independence. What to do then?

\footnotetext{
${ }^{85}$ Fridlund 2011, 85; Derrida 1988: 3-5.

${ }^{86}$ See above; Austin 1976, 14-15.

${ }^{87}$ Cf. Derrida 1988, 64; see also Fridlund 2011, 86.
} 


\section{Mastery, Control and Responsibility}

Austin can be read as working on different levels when writing about performatives. On the one hand, he formulates rules and criteria for performatives to function as such, that is to say, what gives them their force. On the other, he also seems, interestingly enough, to be aware of the fluidity of the categorisation and the difficulty of nailing things down definitively. One implication of this is that Austin distinguishes between particular speech acts as being or not being bound to a set of conventions when producing effects while admitting that this distinction is a slippery one. ${ }^{88}$ Moreover, he perceives the issue of force and effect as a matter of something out of control - at times and under certain circumstances, although not always and not completely. Indeed, he declares, one can make a distinction between producing effects on purpose and doing so without purpose; still, it is also true that the utterer may want to produce an effect that does not take place, as well as having no intention of producing an effect that actually does take place. ${ }^{89}$ Austin argues coherently that what we are engaged in elucidating is the actual phenomenon that takes place in a concrete speech situation in a fashion going beyond purpose and intention. ${ }^{90}$

What comes to the fore here is how to identify the force if the source cannot simply be referred to as a speaker's intention. Is there a mastering voice and an authority? If so, what status can be attributed to it? What character does it have? What if the force does not have a (clear) direction? In which case, what would be the point in speaking about a 'force'? Also, who is then the agent, who is saying? In light of these questions, the issue of whether performatives can be evaluated must be articulated and, if so, how. Ultimately, what is at stake is the understanding of responsibility - who is to blame, for instance - in political discourses. Who is to be held responsible for discourses that perform or, in other words, change, transform and create reality?

At the core lies the question of 'force'. Initially, conventional procedure seems to solve the problem, as has been argued above. There is, however, one component so far neglected. For example, in order for me to have made a promise, it is required that I have been heard and that the hearer has understood me to have made a promise. ${ }^{91}$ For example, 'I bet...' must be followed by someone saying, 'done'. If not, the utterance is not complete, and the performative utterance 'I bet' does not perform. The same holds for 'to promise' and 'to declare war', to pick just two more examples. It is indeed insufficient that the utterer intends and utters something, it must be heard, there must be a response, and some action must follow. ${ }^{92}$

When Austin says that an utterance - like, for instance, 'there is a bull in the field' — can be, but does not have to be, a warning; it can also be sheer description. And in a given situation, it is up to me to hear it as one or the other. ${ }^{93}$ There is a thread of interaction and a part that is uncontrollable and perhaps undecidable. Ingvar Holm similarly addresses the intricate relation between purpose and effect at the theatre. Where should we find purpose and effects? With the sender or the receiver? ${ }^{94}$

\footnotetext{
${ }^{88}$ Austin 1976, 130-132.

${ }^{89}$ Austin 1976, 106-107.

${ }^{90}$ Austin 1976, 138-139, 148; see also Crary 2006, 49.

${ }^{91}$ Austin 1976, 22.

92 Austin 1976, 39-40; Austin 1961, 224-225.

93 Austin 1976, 32-33.

${ }^{94}$ Holm 1991, 46.
} 
I suggest this represents a move in the direction of 'the responsible reader' who hears and who understands. This, too, is beyond the control of the utterer. Austin puts it in positive terms - in order for me to have made a promise, there must be a hearer who hears (and confirms) this promise - but I think it could also be put negatively: although I did not have the intention of making a promise, that is what was heard. I did not know that I was promising, but that is what others perceived.

In general terms, it can be claimed that in order to obtain (desired) effects and consequences when performing an act, a response of a certain kind is required, not just any response, Hominh argues. The response cannot be completely active. The response is not a choice in the same way as when two interlocutors agree upon something as the outcome of negotiations. On the other hand, according to Hominh, the response is not simply the effect which the uttered words have on the interlocutor in the sense of causality. ${ }^{95}$ The effect emerges in a complex relation between utterance and response. ${ }^{96}$ In the context of political discourses, this means that when something is uttered, what is said is not solely or completely constituted by the speaker's intention, but it is not a simple question of negotiations either. President Trump and his audience, for instance, are not two equal partners of the same kind, talking together and simply coming to an agreement regarding what is uttered. (This is so regardless of complications introduced due to the dimension or numbers involved and regardless of the asymmetry in terms of economic and political power.)

On the other hand, the audience does not react in a mechanical way - the effect Trump's words have, for example, is not a simple causality effect, determined by specific laws. It is important to understand how this works, particularly with regard to political discourses, as there is, at some point, an issue of responsibility and accountability. When a political discourse projects and creates, yet it takes the opportunity to talk irresponsibly by not telling the truth about what is at hand, rather suggesting something else, there are effects, precisely to the degree that the discourse has a force. Now where does this force come from? This is a vital question, as one would like to see whether there is someone to criticise for what has been said and for the effects that have been produced.

It is not very difficult to see that there is some kind of interaction and, likewise, that this interactive relationship must be given more attention. The crucial and difficult part is that an established view of such interaction must also be transformed. Interaction is frequently perceived as something in the margin and as an extra. Often we think of an utterance as being produced by someone first, according to an intention and expressing something in particular, and only then is there interaction with someone or some others in the context. Now, if what happens in a discourse is, from the start, also intrinsically dependent on reception and response, this part must get much more attention. That implies considering the role of doubt, not simply security and assurance.

If there is back and forth interaction which cannot be described in terms of negotiation ending in a signed agreement, what takes place in a discourse becomes much more of an open question. Consequently, it becomes inevitable to talk in terms of discernment: what is said and what is meant must be discerned. One will have to discern what is done and what happens. One will have to discern who is to be held responsible. Thus, the tricky part appears to be less about seeing that things happen but, rather, the passage from descriptive analyses to unavoidable interpretations and action. Therein lies perhaps the most important challenge.

95 Hominh 2016, 437.

96 Hominh 2016, 438. 


\section{Concluding Remarks}

Post-truth politics, a political culture in which appeals to emotion outflank facts, is by many perceived as a provocation. Many identify a societal and political crisis in the phenomenon of participants in public deliberations and decision-making processes unhesitatingly presenting alternative facts, without embarrassment. Reactions are vigorous. March for science. Newspaper articles. But also academic articles and books. This is legitimate and understandable. Still, certain aspects tend to be taking over, to the detriment of understanding what is happening.

In this paper, I suggest approaching the issue of post-truth politics with an open mind, as open as possible. The reason is not that I want to advocate a certain policy or way of doing politics, such as those of President Trump, as little as I want to legitimise lies, frauds, fake news and the use of alternative facts. Nonetheless, I argue that, to the extent that one wants to understand post-truth political discourses and in so far as one wants to change the post-truth political climate, it is crucial to see political discourses as discourses that perform rather than report, that is, as being performative. A central issue, then, is what is the force of the performative? I have been arguing that the interesting aspect of understanding political discourses as performative is precisely the character of doing, transforming and changing, which also - and this is extremely important - must include the break with current structures, or, in other words, going outside and beyond established parameters and known patterns. That also means questioning ideas regarding the types of argument that are allowed or the kind of discourse that is appropriate in a given situation. Fuller points out convincingly that 'posttruthers' (his expression) do exactly this. They reject the standards, and by doing, they try to establish another way of doing, talking and arguing. Once again - although I am in agreement with Fuller on this point, I do not like 'post-truthers' and their way of establishing a different political mode - it appears very important to see this. Moreover, I claim that the basic modus operandi of all political discourses is found here, although most of the time perhaps in a much more moderate form.

A structuring idea in this paper is that post-truth political discourses fundamentally function in the way political discourses are supposed to function. Their task is to change and transform reality - or even create a new reality. In this particular sense, they do and they perform. This brings the paper to an investigation of 'performatives'. The point here was not to identify the 'correct' reading of Austin's useful concept; rather, it was to underline that a performative discourse is typically not governed by truth-value. But from where does its force come, and how is the force formed? One approach is to identify and map out procedures and rules, that is to say, the conditions required for an utterance to perform. This is recognised and acknowledged. Yet if political discourses indeed change, transform and create, they will also at certain points break with established frameworks. Here, it is argued that post-truth politics present a precise example of that. But from where does it obtain its force? A speaker's intention appears to be too fragile a means. A discourse, including a performative discourse, a political discourse and perhaps particularly a post-truth one, obtains in relations. The question of accountability and responsibility is then on the table. Here a few indications are given, starting from the idea of 'the responsible reader'. A political discourse in general, and a post-truth political discourse in particular, cannot do and perform - cannot function-in a vacuum. A resonance and a response are required. 
Acknowledgements I would like to thank Lars Gustaf Andersson, Marc Boss, Alexandre Duchêne, Jennifer Geddes and Simone Morehed for their very valuable comments on earlier versions of this article. I am also most grateful for the highly constructive feedback from participants in the research seminar in philosophy of religion and systematic theology at the Centre for Theology and Religious Studies (Lund University) in November 2019 and from the two anonymous reviewers at a late stage in the process. Erik Philip-Sörensens Stiftelse is thanked for a generous grant, which considerably facilitated this study.

Funding Open access funding provided by Lund University. Erik Philip-Sörensens Stiftelse

\section{Compliance with Ethical Standards}

Conflict of Interest The authors declare that they have no conflict of interest.

Open Access This article is licensed under a Creative Commons Attribution 4.0 International License, which permits use, sharing, adaptation, distribution and reproduction in any medium or format, as long as you give appropriate credit to the original author(s) and the source, provide a link to the Creative Commons licence, and indicate if changes were made. The images or other third party material in this article are included in the article's Creative Commons licence, unless indicated otherwise in a credit line to the material. If material is not included in the article's Creative Commons licence and your intended use is not permitted by statutory regulation or exceeds the permitted use, you will need to obtain permission directly from the copyright holder. To view a copy of this licence, visit http://creativecommons.org/licenses/by/4.0/.

\section{References}

Austin JL (1961) Performative utterances. In: Austin JL (ed) Philosophical papers. Clarendon Press, Oxford, pp 220-239

Austin JL (1976) How to do things with words. Oxford University Press, Oxford \& New York

Block D (2019) Post-truth and political discourse. Palgrave Macmillan, Chem

Cervera-Marzal M (2019) Post-vérité. Pourquoi il faut s'en réjouir. Le bord de l'eau, Lormont

Crary A (2006) Austin and the ethics of discourse. In: Crary A, Shieh S (eds) Reading Cavell. Routledge, London \& New York, pp 42-67

da Empoli G (2019) Les ingénieurs du chaos. Lattès, Paris

Derrida J (1988) Limited Inc. Northwestern University Press, Evanston

Derrida J (1999) Donner la mort. Galilée, Paris

Derrida J (2003) Voyous. Deux essais sur la raison. Galilée, Paris

Dieguez S (2019) La cigale et la mante fantôme : une fable de la post-vérité. AOC Media - Analyse Opinion Critique, 22 novembre 2019:1-7

Ford DR (2019) Politics and pedagogy in the "post-truth" era. Insurgent philosophy and praxis. Bloomsbury Academic, London \& New York

Fridlund P (2011) Mobile performances. Linguistic Undecidability as possibility and problem in the theology of religions. Peeters, Leuven

Fuller S (2018) Post-truth. Knowledge as a power game. Anthem Press, London \& New York

Gesellschaft für deutsche Sprache (2016) GfdS wählt "postfaktisch" zum Wort des Jahres 2016. https:/gfds. de/wort-des-jahres-2016/. Accessed 15 October 2020

Habermas J (1984 [1982]) The theory of communicative action 1: reason and the rationalization of society (Theorie des kommunikative Handelns 1). Polity Press, Cambridge

Habermas J (1990) Moral consciousness and communicative action. Polity Press, Cambridge

Holm I (1991) Politik som teater. Från Bastiljen till Helgeandsholmen, Carlssons, Stockholm

Hominh Y (2016) Re-reading the declaration of independence as perlocutionary performative. Res Publica 22: $423-444$

Hyvönen A-E (2018) Careless speech. Conceptualizing post-truth politics. New Perspect 26(3):31-55

Kalpokas I (2018) On guilt and post-truth escapism. Developing a theory. Philos Soc Critic 44(10):1127-1147

Klein N (2017) No is not enough. Resisting the new shock politics and winning the world we need. Allen Lane \& Penguin, London 
Larsson B (1997) Le bon sens commun. Remarques sur le rôle de la (re)cognition intersubjective dans l'épistémologie et l'ontologie du sens. Lund University Press, Lund

Lyotard J-F (2006 [1979]) Au juste. Conversations avec Jean-Loup Thébaud, Bourgois, Paris

Manrique CA (2012) The displacement in Derrida's concept of the "Performative". From the Iterability of Writing to the singularity of Justice. Principos Revista de filosofia 19(32):302-330

Nealon JT (2017) Jokes and the performative in Austin and Derrida; or, the truth is a joke? Cult Crit 95:1-24

Newman S (2019) Post-truth and the crisis of the political. Soft Power 6(2):91-108

Oxford English Dictionaries (2016) The word of the year. https://en.oxforddictionaries.com/word-of-theyear/word-of-the-year-2016. Accessed 26 May 2018

Poole S (2017) Lies, damned lies and alternative facts. The post-truth era isn't new: we all trade in bullshit. New Stateman $42-43$

Renner J, Spencer A (2018) Trump, Brexit \& "post-truth": how post-Structuralist IR theories can help us understand world order in the 21st century. Z Politikwiss 28:315-321

Sayer D (2017) White riot—Brexit, Trump, and post-factual politics. J Hist Sociol 30(1):92-106

Schindler S (2020) The task of critique in times of post-truth politics. Rev Int Stud 46(3):376-394

Searle JR (1969) Speech acts. An essay in the philosophy of language. Cambridge University Press, Cambridge Searle JR (1983) Intentionality. An essay in the philosophy of mind. Cambridge University Press, Cambridge

Sesonske A (1965) Performatives. J Philos 62(17):459-468

Skinner Q (2002) Visions of politics 1: regarding method. Cambridge University Press, Cambridge

Thompson MJ, Smulewicz-Zucker G (eds) (2018) Anti-science and the assault on democracy. Defending Reason in a Free Society. Prometheus Books, Amherst

Trump DJ, Schwartz T (1987) Trump. The Art of the Deal. Ballantine Books, New York

Wikforss $\AA$ (2017) Alternativa fakta. Om kunskapen och dess fiender. Fri tanke, Stockholm 